\title{
PENERAPAN METODE PEMBELAJARAN DI PERGURUAN TINGGI UNTUK MENGHADAPI REVOLUSI INDUSTRI 4.0
}

\author{
Ni'mah Lailatul Mas'adah \\ Institut Agama Islam Syarifuddin Lumajang, Indonesia \\ e-mail: nikma365@gmail.com
}

\begin{abstract}
ABSTRAK
Revolusi industri 4.0 ditandai dengan cyber physical yang mulai diterapkan di berbagai industri masa kini dengan mengembangakan dunia virtual, berupa konektivitas manusia, mesin, dan data yang lebih dikenal dengan Internet of Things (IoT). Ini sebagai bentuk revolusi industri 4.0 yang diperlukan persiapan termasuk metode pembelajaran pendidikan perguruan tinggi secara tepat. Metode pembelajaran yang membutuhkan perhatian guna menjadi simbol persaingan revolusi industri 4.0, diantaranya pengembangan Sumber Daya Manusia, metode pembelajaran pendidikan, teknologi informasi dan komunikasi untuk pembelajaran era revolusi industri 4.0. Metode yang dianggap sesuai untuk diterapkan di revolusi industri 4.0, diantaranya: Pendidikan yang diselenggarakan atas dasar semangat discovery, selanjutnya pendidikan yang diselenggarakan atas semangat berpikir asembling, atau pendidikan yang diselenggarakan untuk melembagakan cara berpikir "perakit". terakhir, memanggil masuk para pelaku pasar dan dunia industri yang berhasil yang dikenal dengan istilah para praktisi atau penggiat dunia usaha dan industri. Jadikan mereka dosen, tanpa pernah memperdulikan title akademiknya. Keempat, pendidikan yang diselenggarakan harus dikembangkan kajian bukan berbasis disiplin ilmu semata tetapi berbasis kebutuhan pasar.
\end{abstract}

Keywords: Metode Pembelajaran, Perguruan Tinggi, Industri 4.0 


\section{Pendahuluan}

Revolusi industri 4.0 adalah konsep yang pertama dikemukakan oleh seorang ekonom Jerman bernama Profesor Klaus Schwab dengan bukunya yang bertajuk "The Fourth Industrial Revolution", Klaus menjabarkan empat tahap revolusi industri yang setiap tahapan memiliki perbedaan dalam sudut pandang cara hidup dan cara kerja manusia. Revolusi industri $4.0 \mathrm{itu}$ sendiri merupakan tahapan terakhir konsep ini setelah tahapan pada abad ke-18, ke-20, dan awal 1970. Disebut-sebut, tahun 2018 merupakan awal zaman revolusi industri 4.0 yang ditandai dengan cyber physical. Berbagai industri masa kini telah menyentuh dunia virtual, berupa konektivitas manusia, mesin, dan data yang lebih dikenal dengan Internet of Things (IoT). Untuk mampu menghadapi revolusi industri 4.0 diperlukan berbagai persiapan termasuk metode pembelajaran pendidikan yang tepat.

Adapun metode pembelajaran yang membutuhkan perhatian dalam menghadapi persaingan revolusi industri 4.0, diantaranya Perbaikan Sumber Daya Manusia, Metode Pembelajaran Pendidikan, Teknologi Informasi dan Komunikasi untuk pembelajaran era revolusi industri 4.0.

Dengan adanya perubahan mendasar era industri di dunia, maka perlu adanya perombakan metode pembelajaran yang tepat sasaran dalam menghadapi era revolusi 4.0. Sehingga diharapkan metode pembelajaran yang seperti apa yang mampu menjadi solusi dalam menghadapi era tersebut.

Penelitian ini berfokus pada tingkatan atau jenjang pendidikan perguruan tinggi, karena jenjang pendidikan tinggi bisa dikatakan mampu menjadi objek yang tepat sasaran untuk percobaan implementasi metode pembelajaran yang baru. Meskipun dalam praktiknya perguruan tinggi di Indonesia masih terfokus pada pembelajaran era Indutri 3.0. 


\section{Pembahasan}

Definisi Industri 4.0 Definisi mengenai Industri 4.0 beragam karena masih dalam tahap penelitian dan pengembangan. Kanselir Jerman, Angela Merkel (2014) berpendapat bahwa Industri 4.0 adalah transformasi komprehensif dari keseluruhan aspek produksi di industri melalui penggabungan teknologi digital dan internet dengan industri konvensional. Schlechtendahl dkk (2015) menekankan definisi kepada unsur kecepatan dari ketersediaan informasi, yaitu sebuah lingkungan industri di mana seluruh entitasnya selalu terhubung dan mampu berbagi informasi satu dengan yang lain.

Pengertian yang lebih teknis disampaikan oleh Kagermann dkk (2013) bahwa Industri 4.0 adalah integrasi dari Cyber Physical System (CPS) dan Internet of Things and Services (IoT dan IoS) ke dalam proses industri meliputi manufaktur dan logistik serta proses lainnya. CPS adalah teknologi untuk menggabungkan antara dunia nyata dengan dunia maya. Penggabungan ini dapat terwujud melalui integrasi antara proses fisik dan komputasi (teknologi embedded computers dan jaringan) secara close loop (Lee, 2008). Hermann dkk (2015) menambahkan bahwa Industri 4.0 adalah istilah untuk menyebut sekumpulan teknologi dan organisasi rantai nilai berupa smart factory, CPS, IoT dan IoS. Smart factory adalah pabrik modular dengan teknologi CPS yang memonitor proses fisik produksi kemudian menampilkannya secara virtual dan melakukan desentralisasi pengambilan keputusan. Melalui IoT, CPS mampu saling berkomunikasi dan bekerja sama secara real time termasuk dengan manusia. IoS adalah semua aplikasi layanan yang dapat dimanfaatkan oleh setiap pemangku kepentingan baik secara internal maupun antar organisasi. Terdapat enam prinsip desain Industri 4.0 yaitu interoperability, 
virtualisasi, desentralisasi, kemampuan real time, berorientasi layanan dan bersifat modular.

Berdasar beberapa penjelasan di atas, Industri 4.0 dapat diartikan sebagai era industri di mana seluruh entitas yang ada di dalamnya dapat saling berkomunikasi secara real time kapan saja dengan berlandaskan pemanfaatan teknologi internet dan CPS guna mencapai tujuan tercapainya kreasi nilai baru ataupun optimasi nilai yang sudah ada dari setiap proses di industri. Model Kerangka Industri 4.0 Usaha untuk menemukan aspek apa saja yang ada di dalam Industri 4.0 tidak cukup dengan hanya melalui pemahaman definisinya. Perlu pemahaman yang lebih komprehensif tentang Industri 4.0 melalui model kerangka konsepnya.

Beberapa penelitian telah dilakukan untuk menyusun model kerangka Industri 4.0. Kagermann dkk (2013) di dalam laporan final kelompok kerja Industri 4.0 yang disponsori oleh kementerian pendidikan dan riset Jerman memberikan rekomendasi model kerangka Industri 4.0. Model yang direkomendasikan merupakan perwujudan dari integrasi tiga aspek. Aspek pertama adalah integrasi horisontal yang berarti mengintegrasikan teknologi CPS ke dalam strategi bisnis dan jaringan kerjasama perusahaan meliputi rekanan, penyedia, pelanggan, dan pihak lainnya. Sedangkan integrasi vertikal menyangkut bagaimana menerapkan teknologi CPS ke dalam sistem manufaktur/ produksi yang ada di perusahaan sehingga dapat bersifat fleksibel dan modular. Aspek yang ketiga meliputi penerapan teknologi CPS ke dalam rantai rekayasa nilai secara end to end. Rantai rekayasa nilai menyangkut proses penambahan nilai dari produk mulai dari proses desain, perencanaan produksi, manufaktur hingga layanan kepada pengguna produk. Integrasi aspek-aspek tersebut memerlukan delapan aksi. Aksi tersebut adalah (1) 
standardisasi, (2) pemodelan sistem kompleks, (3) penyediaan infrastruktur jaringan komunikasi, (4) penjaminan keselamatan dan keamanan, (5) desain organisasi dan kerja, (6) pelatihan sumber daya manusia, (7) kepastian kerangka hukum dan (8) efisiensi sumber daya.

Istilah Industri 4.0 lahir dari ide revolusi industri ke empat. European Parliamentary Research Service dalam Davies (2015) menyampaikan bahwa revolusi industri terjadi empat kali. Revolusi industri pertama terjadi di Inggris pada tahun 1784 di mana penemuan mesin uap dan mekanisasi mulai menggantikan pekerjaan manusia. Revolusi yang kedua terjadi pada akhir abad ke-19 di mana mesin-mesin produksi yang ditenagai oleh listrik digunakan untuk kegiatan produksi secara masal. Penggunaan teknologi komputer untuk otomasi manufaktur mulai tahun 1970 menjadi tanda revolusi industri ketiga. Saat ini, perkembangan yang pesat dari teknologi sensor, interkoneksi, dan analisis data memunculkan gagasan untuk mengintegrasikan seluruh teknologi tersebut ke dalam berbagai bidang industri.

Gagasan inilah yang diprediksi akan menjadi revolusi industri yang berikutnya. Angka empat pada istilah Industri 4.0 merujuk pada revolusi yang ke empat. Industri 4.0 merupakan fenomena yang unik jika dibandingkan dengan tiga revolusi industri yang mendahuluinya. Industri 4.0 diumumkan secara apriori karena peristiwa nyatanya belum terjadi dan masih dalam bentuk gagasan (Drath dan Horch, 2014). Istilah Industri 4.0 sendiri secara resmi lahir di Jerman tepatnya saat diadakan Hannover Fair pada tahun 2011 (Kagermann dkk, 2011).

Negara Jerman memiliki kepentingan yang besar terkait hal ini karena Industri 4.0 menjadi bagian dari kebijakan rencana pembangunannya yang disebut High-Tech Strategy 2020. Kebijakan 
tersebut bertujuan untuk mempertahankan Jerman agar selalu menjadi yang terdepan dalam dunia manufaktur (Heng, 2013). Beberapa negara lain juga turut serta dalam mewujudkan konsep Industri 4.0 namun menggunakan istilah yang berbeda seperti Smart Factories, Industrial Internet of Things, Smart Industry, atau Advanced Manufacturing.

Meski memiliki penyebutan istilah yang berbeda, semuanya memiliki tujuan yang sama yaitu untuk meningkatkan daya saing industri tiap negara dalam menghadapi pasar global yang sangat dinamis. Kondisi tersebut diakibatkan oleh pesatnya perkembangan pemanfataan teknologi digital di berbagai bidang. Industri 4.0 diprediksi memiliki potensi manfaat yang besar. Sebagian besar pendapat mengenai potensi manfaat Industri 4.0 adalah mengenai perbaikan kecepatanfleksibilitas produksi, peningkatan layanan kepada pelanggan dan peningkatan pendapatan.

Terwujudnya potensi manfaat tersebut akan memberi dampak positif terhadap perekonomian suatu negara. Industri 4.0 memang menawarkan banyak manfaat, namun juga memiliki tantangan yang harus dihadapi. Drath dan Horch (2014) berpendapat bahwa tantangan yang dihadapi oleh suatu negara ketika menerapkan Industri 4.0 adalah munculnya resistansi terhadap perubahan demografi dan aspek sosial, ketidakstabilan kondisi politik, keterbatasan sumber daya, risiko bencana alam dan tuntutan penerapan teknologi yang ramah lingkungan. Menurut Jian Qin dkk (2016), terdapat kesenjangan yang cukup lebar dari sisi teknologi antara kondisi dunia industri saat ini dengan kondisi yang diharapkan dari Industri 4.0.

Penelitian yang dilakukan oleh Balasingham (2016) juga menunjukkan adanya faktor keengganan perusahaan dalam menerapkan Industri 4.0 karena kuatir terhadap ketidakpastian manfaatnya. 
Berdasarkan beberapa penjelasan tersebut maka sesuai dengan yang disampaikan oleh Zhou dkk (2015), secara umum ada lima tantangan besar yang akan dihadapi yaitu aspek pengetahuan, teknologi, ekonomi, social, dan politik. Guna menjawab tantangan tersebut, diperlukan usaha yang besar, terencana dan strategis baik dari sisi regulator (pemerintah), kalangan akademisi maupun praktisi. Kagermann dkk (2013) menyampaikan diperlukan keterlibatan akademisi dalam bentuk penelitian dan pengembangan untuk mewujudkan Industri 4.0. Menurut Jian Qin dkk (2016) roadmap pengembangan teknologi untuk mewujudkan Industri 4.0 masih belum terarah. Hal ini terjadi karena Industri 4.0 masih berupa gagasan yang wujud nyata dari keseluruhan aspeknya belum jelas sehingga dapat memunculkan berbagai kemungkinan arah pengembangan. Artikel ini bertujuan untuk menelaah aspek dan arah perkembangan riset terkait Industri 4.0.

Pendekatan yang digunakan adalah studi terhadap beragam definisi dan model kerangka Industri 4.0 serta melalui pemetaan dan analisis terhadap sejumlah publikasi. Isi artikel ini meliputi kajian terhadap definisi dan model kerangka Industri 4.0 guna menemukan aspek apa saja yang ada di dalam konsep Industri 4.0. Berikutnya adalah penjelasan mengenai metode untuk menelusuri arah perkembangan riset Industri 4.0, dilanjutkan dengan pembahasan hasil dan kesimpulan. Artikel ini diharapkan dapat memberi gambaran mengenai apa itu Industri 4.0, perkembangan dan potensi riset yang ada di dalamnya.

\section{Metode Penelitian}

Riset penelitian ini menggunakan metode penelitian kualitatif. Menurut Lexy J. Moleong (2005:6), metode penelitian kualitatif adalah suatu riset yang bermaksud untuk memahami fenomena yang dialami 
oleh subjek penelitian. Misalnya perilaku, persepsi, motivasi, tindakan, dan lain-lain, secara holistic, dan dengan cara deskripsi dalam bentuk kata-kata dan bahasa, pada suatu konteks khusus yang alamiah dan dengan memanfaatkan berbagai metode alamiah.

Menurut Sugiyono (2009:15), pengertian penelitian kualitatif adalah penelitian yang berlandaskan pada filsafat post positivisme, digunakan untuk meneliti pada kondisi obyek yang alamiah, (sebagai lawannya eksperimen) dimana peneliti adalah sebagai instrumen kunci, pengambilan sampel sumber data dilakukan secara purposive dan snowball, teknik pengumpulan dengan tri-anggulasi (gabungan), analisis data bersifat induktif atau kualitatif, dan hasil penelitian kualitatif lebih menekankan makna dari pada generalisasi.

Di dalam proses pengumpulan data riset ini menggunakan pendekatan deskriptif analitik dengan melakukan pengamatan, analisis dan dokumentasi dimana bentuknya tidak berupa angka. Analisis data berupa pemaparan tentang situasi yang diteliti dimana penyajiannya dalam bentuk uraian narasi. Riset ini termasuk ke dalam jenis penelitian kualitatif fenomenologi. Menurut Richard Johnson (2005:8), Fenomenologi adalah suatu bentuk penelitian di mana peneliti berusaha untuk memahami bagaimana satu atau lebih individu mengalami suatu fenomena. Metode penelitian ini dimulai dengan memperhatikan dan menelaah fokus pada fenomena yang diteliti dan memperhatikan aspek subjektif dari perilaku objek. Berikutnya, peneliti menggali informasi dengan pemaknaan atau memberikan arti terhadap fenomena yang diteliti. 


\section{Pembahasan}

Jika dunia industri tengah dihadapkan pada tantangan era generasi keempat (4.0), maka berbeda halnya dengan pendidikan tinggi di Indonesia yang saat ini masih bergelut dengan ragam tantangan di era generasi ketiganya (3.0). Kondisi ini ditandai dengan tuntutan akan peningkatan kualitas pembelajaran dan meninggalkan pola kebijakan lama yang sekadar berkutat pada masalah pemerataan akses serta pemenuhan sarana prasarana pendidikan.

Perubahan pola kebijakan yang berorientasi pada kualitas pembelajaran ini selaras dengan tuntutan tentang apa dan bagaimana seharusnya pendidikan di Indonesia sebagai media penyiapan sumber daya manusia yang siap terlibat dalam tantangan Revolusi Industri 4.0 tersebut. Pertanyaan yang pasti muncul adalah, "Siapkah kita memenuhi tuntutan sekaligus menghadapi tantangan revolusi industri 4.0?" Berikut merupakan gambaran implementasi metode pendidikan yang ada di Indonesia beserta dampak kalusulnya dilihat dari beberapa aspek, diantaranya :

\section{Kurikulum}

Penyelarasan pembelajaran dalam tataran praktik yang disesuaikan pada konstruk kurikulum yang telah ada menjadi fokus pertama dalam penyelesaian 'pekerjaan rumah' pemerintah dalam bidang pendidikan. Kebijakan Kurikulum harus mengelaborasi kemampuan peserta didik pada dimensi pedagogik, kecakapan hidup, kemampuan hidup bersama (kolaborasi), dan berpikir kritis dan kreatif. Ini yang kemudian disinggung pada awal tulisan, yaitu pengedepanan 'soft skills' dan 'transversal skills', keterampilan hidup, dan keterampilan yang secara 
kasat tidak terkait dengan bidang pekerjaan dan akademis tertentu. Namun, hal itu bermanfaat luas pada banyak situasi pekerjaan layaknya kemampuan berpikir kritis dan inovatif, keterampilan interpersonal, warga negara yang berwawasan global, dan literasi terhadap media dan informasi yang ada.

Banyak kajian mengemukakan bahwa implementasi kurikulum di lapangan mengalami degradasi yang keluar konteks dan tidak lagi berorientasi pada pencapaian kemampuan peserta didik pada pemahaman ilmu dalam konteks praktik hidup dan keseharian (kompetensi keterampilan hidup), namun hanya berkisar pada target pencapaian kompetensi peserta didik yang digambarkan pada nilai-nilai akademik semata. Artinya, implementasi kurikulum di lapangan mengalami degradasi yang keluar konteks dan tidak lagi berorientasi pada pencapaian kemampuan peserta didik tersebut pada pemahaman ilmu dalam konteks praktik hidup dan keseharian.

\section{Metode Belajar}

Menstimulus kemampuan peserta didik melalui beragam terobosan metode belajar kontekstual yang mendorong peserta didik berpikir kritis dalam beragam konteks hidup yang nanti dihadapinya, seperti problembased learning, inquiry-based learning, pendekatan pembelajaran Science, Technology, Engineering, Arts, dan Mathematics (STEAM), dan ragam pendekatan pembelajaran lainnya. Sehingga tidak sekadar berfokus pada pola-pola lama dan monoton pada pembelajaran yang minim kreativitas.

Selama ini kita banyak beranggapan bahwa dosen adalah kunci keberhasilan sebuah praktik pembelajaran pada peserta didik, tetapi lupa untuk mengakui bahwa dosen tidak lagi menjadi satu-satunya sumber 
belajar peserta didik. Pola dan metode pembelajaran lama sering kali menempatkan dosen menjadi satu-satunya sumber belajar dan 'maha tahu' di dalam ruang kelas, seolah melupakan bahwa peserta didik yang merupakan subjek belajar pun sesungguhnya merupakan sumber belajar bagi rekan sejawatnya.

Metode pembelajaran yang beragam dan membuka keleluasaan dosen dalam mengeksplorasi peserta didik dan pola pembelajaran yang dijalankan di kelas, diharapkan akan juga memperluas wawasan peserta didik tentang kontekstualisasi ilmu yang didapatkannya di dalam kelas menuju praktik hidup yang dihadapinya nanti sebagai bagian dari realitas kehidupan. Membuka banyak kesempatan dan peluang kepada peserta didik, dosen, kampus, dan iklim pendidikan secara luas untuk mengembangkan cakupan sumber belajar yang dimilikinya, baik dari sumber yang sifatnya tangible maupun intangible, akademis ataupun non akademis, tanpa batasan aksesibilitas atas sumber belajar tersebut. Dalam hal ini, perguruan tinggi melalui kebijakan-kebijakannya harus hadir dalam mengakomodir kebutuhan tersebut. Selama ini kita banyak beranggapan bahwa dosen adalah kunci keberhasilan sebuah praktik pembelajaran pada peserta didik, tetapi lupa untuk mengakui bahwa dosen tidak lagi menjadi satu-satunya sumber belajar peserta didik.

\section{Penguasaan Data, Informasi, dan Teknologi}

Menstimulus dan memfasilitasi peserta didik serta masyarakat pendidikan untuk menguasai data dan informasi secara global, serta teknologi informasi yang dielaborasi dengan menciptakan ruang-ruang kreativitas dan ragam peluang yang memberikan keuntungan ekonomi yang sifatnya luas. Dalam hal ini, perguruan tinggi harus dapat mengakomodir infrastruktur digital yang dibutuhkan peserta didik dan 
masyarakat pendidikan untuk meniscayakan penguasaan data, informasi, serta teknologi tersebut.

\section{Kapasitas yang Adaptif}

Mendorong perkembangan pendidikan berbasis vokasional, dengan ragam keterampilan yang tidak sekadar mengedepankan konsep link and match antara perguruan tinggi dengan dunia industri, tetapi juga menekankan kapasitas lulusan yang lincah, adaptif, dan sensitif terhadap perubahan lingkungan industri dan ekonomi. Keseimbangan pemahaman antara konsep pengetahuan dan keterampilan adalah hal yang penting, tetapi belum cukup bagi mahasiswa untuk dapat memahami cepatnya perubahan lingkungan. Survival of the fittest sepertinya akan berlaku di era generasi keempat ini. Hanya mereka yang adaptiflah, yang akan survive terhadap gempuran Revolusi Industri 4.0 ini. Survival of the fittest sepertinya akan berlaku di era generasi keempat ini. Hanya mereka yang adaptiflah, yang akan survive terhadap gempuran Revolusi Industri 4.0.

Menghadapi revolusi industri 4.0 tentu bukan hal mudah, paling tidak, ada dua arus utama pendidikan tinggi yang dapat ditawarkan kepada masyarakat, yaitu merekonstruksi ulang model pendidikan Perguruan tinggi agar tetap pada pada arahnya sebagai produsen sumber daya manusia yang unggul dan dibutuhkan masyarakat secara luas, dan membangun inovasi pembelajaran yang ada saat ini. Kuantitas bukan lagi menjadi indikator utama bagi suatu perguruan tinggi dalam mencapai kesuksesan, melainkan kualitas lulusannya. Perguruan Tinggi wajib dapat menjawab tantangan untuk menghadapi kemajuan teknologi dan persaingan dunia kerja di era globalisasi. Dalam menciptakan sumber daya yang inovatif dan adaptif terhadap teknologi, diperlukan 
penyesuaian sarana dan prasarana pembelajaran dalam hal teknologi informasi, internet, analisis big data dan komputerisasi.

Perguruan tinggi yang menyediakan infrastruktur pembelajaran tersebut diharapkan mampu menghasilkan lulusan yang terampil dalam aspek literasi data, literasi teknologi dan literasi manusia. Terobosan inovasi akan berujung pada peningkatan produktivitas industri dan melahirkan perusahaan pemula berbasis teknologi, seperti yang banyak bermunculan di Indonesia saat ini. Tantangan berikutnya adalah rekonstruksi kurikulum pendidikan tinggi yang responsif terhadap revolusi industri juga diperlukan, seperti desain ulang kurikulum dengan pendekatan human digital dan keahlian berbasis digital. Persiapan dalam menghasilkan lulusan yang mampu beradaptasi dengan Revolusi Industri 4.0 adalah salah satu cara yang dapat dilakukan Perguruan Tinggi untuk meningkatkan daya saing terhadap kompetitor dan daya tarik bagi calon mahasiswa.

Perguruan tinggi Indonesia perlu merubah tiga hal dari sisi edukasi, yang paling fundamental adalah mengubah sifat dan pola pikir peserta didik. Selanjutnya, kampus harus bisa mengasah dan mengembangkan bakat peserta didiknya. Terakhir, Perguruan tinggi seharusnya mampu mengubah model pembelajaran yang sesuai dengan kebutuhan zaman kiwari dengan fokus pada Konsep 'KKN' (komunikasi, kolaborasi, dan networking). Berdasarkan hal tersebut diatas, maka perguruan tinggi harus bisa meramu metode pendidikan baru yang mampu menyesuaikan kebutuhan di era kekinian, yaitu : 
Pertama, Pendidikan yang diselenggarakan atas dasar semangat discovery. Model pendidikan semacam ini mengorientasikan kegiatannya untuk dapat meraih "penemuan-penemuan" besar yang berguna bagi perubahan-perubahan kehidupan manusia di masa depan. Riset-risetnya dilakukan atas dasar "kerja kolektif" untuk diarahkan pada "penyelesaian masalah-masalah besar" dan "penemuan-penemuan besar" sehingga metode pendidikan yang diselenggarakan perguruan tinggi harus benar benar fokus bidang kajian prodi keilmuan yang diselenggarakan.

Kedua, pendidikan yang diselenggarakan atas semangat berpikir asembling, atau pendidikan yang diselenggarakan untuk melembagakan cara berpikir "perakit", sehingga tugas utamanya melahirkan sebanyakbanyaknya tenaga ahli perakit yang sangat dibutuhkan oleh dunia usaha dan industri. Pendidikan seperti ini mungkin mirip pendidikan vokasi, tetapi bedanya terletak pada "cara berpikir" yang luas, melintas disiplin, dan kompetensi yang dihasilkannya mampu melahirkan produk-produk baru, baik berupa barang maupun jasa. Mungkin pendidikan semacam ini tepat disebut "pendidikan vokasi plus". Dibeberapa negara Asia tampaknya telah memberi perhatian besar terhadap pengembangan pendidikan semacam ini.

Ketiga, memanggil masuk para pelaku pasar dan dunia industri yang berhasil yang dikenal dengan istilah para praktisi atau penggiat dunia usaha dan industri. Jadikan mereka dosen, tanpa pernah memperdulikan title akademiknya. Mereka diminta menyampaikan secara gamblang apa yang mereka lakukan setiap saat sehingga peserta didik memiliki semangat dan motivasi untuk bisa seperti mereka. Kehadiran mereka akan dapat memeberikan perubahan dan membuat terobosan kehidupan, baik dari aspek sains, kedokteran, sastra atau humaniora. 
Keempat, pendidikan yang diselenggarakan harus dikembangkan kajian bukan berbasis disiplin ilmu semata tetapi berbasis kebutuhan pasar. Titel akademik tidak lagi yang menentukan spesifikasi, tapi sertifikat ahli dari figur sentral dalam keilmuan yang ditekuni. Kuliah tidak perlu ditawarkan di ruang kelas, tapi di tempat praktek yang ditentukan oleh patron tadi. Datangkan 'futurelog' yang bisa memprediski revolusi kehidupan apa yang akan terjadi ke depan. Dunia pendidikan segera bergerak ke arah sana.

\section{Kesimpulan}

Dunia Pendidikan saat ini tidak terlepas dari era Revolusi industri 4.0. pemenuhan sarana prasarana pendidikan.Perubahan pola kebijakan yang berorientasi pada kualitas pembelajaran ini selaras dengan tuntutan tentang apa dan bagaimana seharusnya pendidikan di Indonesia sebagai media penyiapan sumber daya manusia yang siap terlibat dalam tantangan Revolusi Industri 4.0. Perubahan pola kebijakan yang berorientasi pada kualitas pembelajaran ini selaras dengan tuntutan tentang apa dan bagaimana seharusnya pendidikan di Indonesia sebagai media penyiapan sumber daya manusia yang siap terlibat dalam tantangan Revolusi Industri 4.0. Dengan menyelenggarakan empat arus utama pendidikan tinggi semacam itu, selaian eksistensi pendidikan tinggi tetap dapat dipertahankan, maka pendidikan tinggi dikembalikan lagi perannya sebagai pemandu atau penuntun peradaban manusia, bukannya sebagai pembebek (pengekor) apa saja yang telah dilakukan oleh dunia kerja dan dunia industri. 


\section{Daftar Pustaka}

Kagermann, H., Lukas, W.D., \& Wahlster, W., 2011, Industrie 4.0: Mit dem Internet der Dinge auf dem Weg zur 4. industriellen Revolution. http://www.vdinachrichten.com/Technik-Gesellschaft/Industrie40- Mit-Internet-Dinge-Weg-4-industriellen-Revolution, Diakses pada 17 Juni 2017.

Kagermann, H., Lukas, W.D., \& Wahlster, W., 2013, Final report: Recommendations for implementing the strategic initiative INDUSTRIE 4.0. Industrie 4.0 Working Group

Lee, E.A., 2008, Cyber physical systems: Design challenges. In Object Oriented Real-Time Distributed Computing (ISORC), 11th IEEE International Symposium, pp. 363-369..

Merkel, A., 2014, Speech by Federal Chancellor Angela Merkel to the OECD Conference. https://www.bundesregierung.de/Content/EN/Reden/ 2014/2014-02-19-oecd-merkel-paris_en.html, Diakses pada 11 Maret 2017.

Schlechtendahl, J., Keinert, M., Kretschmer, F., Lechler, A., \& Verl, A., 2015, Making existing production systems Industry 4.0-ready. Production Engineering, Vol. 9, Issue.1, pp.143-148.

Drath, R., \& Horch, A., 2014, Industrie 4.0: Hit or hype?[industry forum]. IEEE industrial electronics magazine, 8(2), pp. 56-58

Qin, J., Liu, Y., \& Grosvenor, R., 2016, A Categorical Framework of Manufacturing for Industry 4.0 and Beyond. Procedia CIRP, Vol. 52, pp. 173-178.

Zhou, K., Taigang L., \& Lifeng, Z., 2015, Industry 4.0: Towards future industrial opportunities and challenges. In Fuzzy Systems and Knowledge Discovery (FSKD), IEEE 12th International Conference, pp. 2147-2152

Balasingham, K., 2016, Industry 4.0: Securing the Future for German Manufacturing Companies. Master's Thesis. University of Twente.

Moleong Lexy J., 2005, Metodologi Penelitian Kualitatif, Bandung: Remaja Rosdakarya. 
Penerapan Metode Pembelajaran di Perguruan Tinggi untuk Menghadapi Revolusi Industri 4.0

Sugiyono, 2009, Metode Penelitian Pendidikan Pendekatan Kuantitatif, kualitatif, dan RED. Bandung: Alfabeta

Johnson, Richard, 2007, Applied Multivariate Statistical Analysis, Prentice Hall, United States of America 